\title{
Investigation of Aloe vera barbadensis Miller Leaf Extract Effects On Glutamate and Glufosinate Induced Toxicity: In Vitro Study
}

\author{
Ayşegül YILMAZ ${ }^{1}$ Ali TAGHIZADEHGHALEHJOUGHI ${ }^{1,2 *}$ \\ Aybike TÜRKMEN ${ }^{3}$ \\ ${ }^{1}$ Ataturk University, Faculty of Medicine, Department of Medical Pharmacology, Erzurum, Turkey \\ ${ }^{2 *}$ Ataturk University, Faculty of Veterinary Medicine, Department of Pharmacology and Toxicology, Erzurum, Turkey \\ ${ }^{3}$ Adnan Menderes University, Faculty of Veterinary Medicine, Department Pharmacology and Toxicology, Aydin, Turkey
}

How to cite: Yılmaz, A., Taghizadehghalehjoughi, A., Hacımüftüoğlu, A. \& Türkmen, A. (2021). Investigation of Aloe vera barbadensis Miller Leaf Extract Effects On Glutamate and Glufosinate Induced Toxicity: In Vitro Study. J. Anatolian Env. and Anim. Sciences, 6(3), 376-381.

Atıf yapmak için: Yılmaz, A., Taghizadehghalehjoughi, A., Hacımüftüoğlu, A. \& Türkmen, A. (2021). Aloe vera barbadensis Miller Yaprağı Ekstraktının Glutamat ve Glifosat Kaynaklı Toksisite Üzerindeki Etkilerinin Araştırılması: İn Vitro Çalışması. Anadolu Çev. ve Hay. Dergisi, 6(3), 376-381.

: https://orcid.org/0000-0001-5843-1661 : https://orcid.org/0000-0002-3506-0324 : https://orcid.org/0000-0002-9658-3313 D : https://orcid.org/0000-0002-4119-7490

*Corresponding author's: Ali TAGHIZZADEHGHALEHJOUGHi Ali Taghizadehghalehjoughi, Faculty of Veterinary Medicine, Department of Pharmacology and Toxicology, Ataturk University, Erzurum, Turkey. 凶: ali.tgzd@atauni.edu.tr

\begin{abstract}
Aloe vera is one of the medicinal plants whose importance has been better understood recently with its antibacterial, antimicrobial, antioxidant and anticancer properties. Although it is known that the aloe vera family has protective effects on neurons, the neuroprotective effect of the aloe barbadensis miller plant has not yet been fully explained. Glufosinate is structurally similar to glutamate and is an herbicide that blocks glutamine synthesis. Glutamate has been shown to induce cyclooxygenase-2 (COX-2), which causes toxicity. In the present study, neuron culture was exposed to Aloe vera barbadensis Miller plant extracts plant $(25,50,100,200,400$, 800 , and $1600 \mu \mathrm{gr} / \mathrm{ml}$ doses $)$ for 24 hours to protect against glufosinate $(200 \mathrm{mM})$ and glutamate $\left(10^{-5} \mathrm{mM}\right)$ toxicity. After 24 hours, MTT, TAC, and TOS analyzes were performed and the results were revealed. In our study, it was seen that the aqueous extract of aloe barbadensis miller plant, glufosinate, and glutamate, could preserve the vitality of neurons (89\% protection in AVB 400 $\mu \mathrm{gr} / \mathrm{ml}$ group). At the same time, it was seen that while increasing the antioxidant level in neurons, it decreased the oxidant level. The group that increases the antioxidant value best is AVB 400 $\mu \mathrm{gr} / \mathrm{ml}$ (the group that increases it 1.4 times). When the findings were evaluated, it was concluded that aloe vera and its components may have a neuroprotective effect.
\end{abstract}

Keywords: Aloe vera barbadensis Miller, glufosinate, glutamate, neuron.

\section{Aloe vera barbadensis Miller Yaprağı Ekstraktının Glutamat ve Glifosat Kaynaklı Toksisite Üzerindeki Etkilerinin Araştırılması: İn Vitro Çalışması}

*Sorumlu yazar:

Ali TAGHIZADEHGHALEHJOUGHi Atatürk Üniversitesi, Veteriner Fakültesi, Farmakoloji ve Toksikoloji Bölümü, Erzurum, Türkiye.

$\varangle$ : ali.tgzd@atauni.edu.tr
Öz: Antibakteriyel, antimikrobiyal, antioksidan ve antikanser gibi özellikleriyle son zamanlarda önemi daha da iyi anlaşılan Aloe vera şifalı bitkilerden biridir. Aloe vera ailesinin nöronlar üzerinde koruyucu etkileri olduğu bilinmesine rağmen aloe barbadensis miller bitkisinin nöroprotektif etkisi henüz tam olarak açıklanamamıştır. Glufosinat, yapısal olarak glutamata benzer ve glutamin sentetazı bloke eden bir herbisittir. Glutamatın toksisiteye neden olan siklooksijenaz-2'yi (COX-2) indüklediği gösterilmiştir. Ayrıca nöronlarda oksidatif strese neden olduğu bilinmektedir. Mevcut çalışmada, nöron kültürü, glufosinat $(200 \mathrm{mM})$ ve glutamat $\left(10^{-5}\right.$ $\mathrm{mM}$ ) toksisitesine karşı korunmak amacıyla 24 saat süreyle Aloe vera barbadensis Miller bitkisi ekstraktlarına $(25,50,100,200,400,800 \mathrm{ve} 1600 \mu \mathrm{gr} / \mathrm{ml})$ maruz bırakılmış olup, 24 saat sonunda MTT, TAC ve TOS analizleri yapılmıştır. Çalışmamızda aloe barbadensis miller bitkisinin sulu ekstraktının, glufosinat ve glutamat toksisitesine karşı nöron canlılığını koruyabildiği görülmüştür (AVB $400 \mu \mathrm{gr} / \mathrm{ml}$ grubunda $\% 89$ koruma). Aynı zamanda nöronlarda antioksidan seviyesini arttırırken oksidan seviyesini azalttığı gözlemlenmiştir. Antioksidan değerini en iyi artıran grup AVB $400 \mu \mathrm{gr} / \mathrm{ml}$ (1,4 kat artıran grup) olarak tespit edilmiştir. Elde edilen bulgular değerlendirildiğinde, aloe vera ve bileşenlerinin nöroprotektif etkisi olabileceği sonucuna varılmıştır.

Anahtar kelimeler: Aloe vera barbadensis Miller, glufosinat, glutamat, nöron. 


\section{INTRODUCTION}

Aloe vera barbadensis Miller (AVB), one of the well-known medicinal plants recently, is preferred because of its multiple effects. This medicinal plant belongs to the Liliaceae family and is widely used in traditional medicine. The compounds found in aloe gel mainly contain polysaccharides that reduce inflammation and induce skin growth and regeneration. Recent studies have also shown that it has antibacterial, antimicrobial, antioxidant and anticancer properties (Khanal et al., 2021, Mahboubi, 2021). Although it is known that the aloe vera family has protective effects on neurons, the neuroprotective effect of the Aloe vera barbadensis Miller plant is not yet well known. Aloe vera and its components contain various properties. For example; salicylic acid, campesterol, $\beta$ sitosterol and C-glucosyl chromone are anti-inflammatory, vitamins $\mathrm{A}, \mathrm{C}$ and $\mathrm{E}$ are anti-oxidant, anthraquinones and phorbol myristic acetate are anti-tumor, aloin and emodin are anti-microbial (Klaikeaw et al., 2020).

The use of pesticides in agriculture, industry, and domestic applications results in increased exposure to these chemicals (Sevim et al., 2019). As a result of acute exposure, it has been observed that human health is highly affected. Glufosinate is one of the most widely used herbicide-based pesticides worldwide (Comakli et al., 2019). Glufosinate, which is one of the main pollutants of rivers and various water resources, has a toxic effect not only on organisms, but also on food, feed and ecosystems (Singh et al., 2020). The European Chemicals Agency concludes that there are insufficient scientific data to classify glufosinate as a carcinogen, mutagen or reproductive toxicity for certain target organ toxicity (Levine et al., 2020, Matozzo et al., 2020, Pereira et al., 2021). Glufosinate toxicity was done by induction glutamate toxicity in inter synaptic area.

Glutamate is the principal excitatory neurotransmitter in the central nervous system. Elevated extracellular glutamate levels induce neuronal damage (Kumagai et al., 2019). In cerebral hypoxia/anoxia, and in the majority of nervous system diseases, glutamate transporter function is impaired, and extracellular glutamate levels increase and result in irreversible neuronal damage (Tehse \& Taghibiglou, 2019). In addition, by attaching to N-methyl-d-aspartate (NMDA) and AMPA receptors for longer than physiological levels, glutamate causes $\mathrm{Ca}^{++}$and $\mathrm{Na}^{+}$influx. Strong evidence also exists that glutamate toxicity is significantly associated with NMDA receptors. These receptors are also significantly involved in the central sensitization processes associated with hyperalgesia (Zhao et al., 2019).

Previous studies of maternal exposure to Glufosinate have shown that pre- and postnatal exposures lead to calcium overload and glutamate excitotoxicity in the immature juvenile hippocampus (Cattani et al., 2017). The purpose of the present study was to evaluate different doses of Aloe vera barbadensis neuro protective effects against to Glufosinate and glutamate toxicity in vitro model.

\section{MATERIALS AND METHODS}

Chemicals: Aloe vera barbadensis (1000 mg film-coated tablets), was obtained from (Izmir, Turkey). Glufosinate, glutamate HCL, Dulbecco's modified Eagle's medium (DMEM), Fetal calf serum (FCS), Neurobasal medium (NBM), 3-(4,5-Dimethylthiazol-2-yl)-2,5Diphenyltetrazolium Bromide (MTT), phosphate buffer solution (PBS), antibiotic antimitotic solution (100×), B27, L glutamine and trypsin-EDTA and dimethyl sulfoxide (DMSO) were obtained from Sigma-Aldrich (St. Louis, MO, USA).

\section{In vitro studies}

Cell cultures: Briefly, frozen cortex neuron cells were used for the study $\left(\right.$ Gibco $^{\mathrm{TM}}$ Primary Rat Cortex Neurons, Catalog no: A1084001). The cryotube was open rapidly and centrifugation was done at $1200 \mathrm{rpm}$ for $5 \mathrm{~min}$. The collapsed cells were suspended with fresh medium (Neurobasal medium, FBS 10\%, B27 2\% and antibiotic $0.01 \%$ ) and then the cells were seeded in 24-well plates (Corning, USA). The plate was stored in an incubator (5\% $\mathrm{CO}_{2} ; 37^{\circ} \mathrm{C}$ ) (Varmazyari et al., 2020).

Glutamate and Glufosinate toxicity induction): Adequate branches were observed to have formed in the cells by day 10 . Glutamate $10^{-5} \mathrm{mM}$ and Glufosinate 200 $\mathrm{mM}$ were used for toxicity induction. After $20 \mathrm{~min}, \mathrm{ABV}$ different concentrations (50, 100, 200, 400, 800 and 1600 $\mu \mathrm{gr} / \mathrm{ml})$ were added to each well and incubated for $24 \mathrm{~h}$ $\left(5 \% \mathrm{CO}_{2} ; 37{ }^{\circ} \mathrm{C}\right)$. These selected concentrations were added as a result of the literature search (Kang et al., 2014; Kaithwas et al., 2014; Klaikeaw et al., 2020). In addition, $150 \mu \mathrm{L}$ of NBM only was added as a negative control, while the two positive controls each one contained separately $10^{-5} \mathrm{mM}$ glutamate and $200 \mathrm{mM}$ glufosinate ( Singh et al., 2020).

\section{3-(4,5-Dimethylthiazol-2-yl)-2,5-Diphenyltetra-} zolium Bromide (MTT) assay: MTT assay was according to the commercial kit protocol. Briefly, MTT reagent (10 $\mu \mathrm{L})$ was added to the each well and incubated $\left(5 \% \mathrm{CO}_{2} ; 37\right.$ ${ }^{\circ} \mathrm{C}$ ) for $4 \mathrm{~h}$. The medium was removed, then $100 \mu \mathrm{L}$ of dimethyl sulfoxide was added to each well. The optical density was evaluated at $570 \mathrm{~nm}$ using a Multiskan ${ }^{\text {TM }}$ GO Microplate Spectrophotometer reader (Thermo Scientific, 
Canada, USA) (Taghizadehghalehjoughi et al., 2019). the cell viability (\%) was calculated using the formula.

Viability \% ratio: Sample Absorbance/control group absorbance $\times 100$.

Total oxidant status (TOS): TOS assay was done according to the commercial manufacture kit protocol. Briefly, $500 \mu 1$ Reactive 1 solution was added to wells and the initial absorbance value at $530 \mathrm{~nm}$. then 25 $\mu 1$ Reactive 2 solution was added to the same well, and the second absorbance was read at $530 \mathrm{~nm}$. TOS levels were determined as $\mathrm{H}_{2} \mathrm{O}_{2} \mathrm{mmol}$ equiv $/ \mathrm{mmol}^{-1}$.

The evaluation was done according the formula.

TOS $=\Delta$ example $/ \Delta \mathrm{ST} 2 \times 20$

$\Delta$ ST2 $(\Delta$ standard $2=$ ST2 second reading - ST2 first reading $), \Delta$ Sample $(\Delta$ Sample $=$ Sample second readingSample first reading)

Total Antioxidant Capacity (TAC): TAC assay was done according to the commercial manufacture kit protocol. Briefly, $500 \mu$ l Reactive 1 solution was added to wells and the first absorbance was read at $660 \mathrm{~nm}$. Next, $75 \mu$ Reactive 2 was added to the same wells and the second absorbance value was read at $660 \mathrm{~nm}$. TAC levels were expressed as mmol equiv/mmol-1.

The evaluation was done according the formula;

$\mathrm{TAC}=(\Delta \mathrm{ST} 1-\Delta$ example $) /(\Delta \mathrm{ST} 1-\Delta \mathrm{ST} 2)$

$\Delta$ ST1 $(\Delta$ standard $1=$ ST1 second reading - ST1 first reading), $\Delta \mathrm{ST} 2(\Delta$ standard $2=\mathrm{ST} 2$ second reading $-\mathrm{ST} 2$ first reading $), \Delta$ Sample $(\Delta$ Sample $=$ Sample second reading-Sample first reading)

Statistical analysis: The analysis of the data of our study was evaluated with SPSS 21.0 program and One Way Annova method and $\mathrm{P}<0.05$ was considered significant.

\section{RESULTS AND DISCUSSION}

In our study, the protective effects of Aloe vera barbadensis on neuronal cells against glutamate and glufosinate were investigated. For this purpose, MTT, TAC and TOS analyzes were performed 24 hours after the application and the results were shown in the figures.

When the MTT test in Figure 1 and 2 were examined, it was seen that AVB protected neuron viability against glutamate and glufosinate depending on the increasing dose. The best protection was seen in the AVB $400 \mu \mathrm{gr} / \mathrm{mL}$ (89\%) group against glutamate, which caused a $31 \%$ decrease in viability. The highest protection against glufosinate toxicity was seen at the AVB 200 dose (85\% protection). The neuroprotection rate of the same group against glufosinate toxicity (reduces viability by $36 \%$ ) is $82 \%$. While it was observed that the AVB $800(86 \%)$ and $1600(83 \%) \mu \mathrm{gr} / \mathrm{mL}$ groups also protected neuron cells against glutamate, the viability was decreased compared to the AVB $400 \mu \mathrm{gr} / \mathrm{mL}$ group. In glufosinate toxicity, viability was $8 \%$ (78\%) lower in the AVB $800 \mu \mathrm{gr} / \mathrm{mL}$ group and $13 \%(70 \%)$ in the AVB $1600 \mu \mathrm{gr} / \mathrm{mL}$ group against glutamate toxicity.

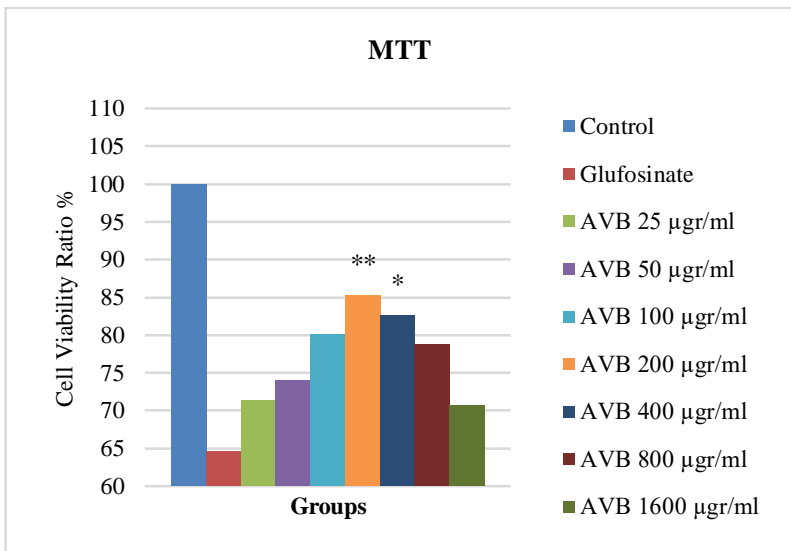

Figure 1. 3-(4,5-dimethylthiazol-2-yl)-2,5-diphenyltetrazolium bromide (MTT) assay results for the Glufosinate induced toxicity in the neuron cell line after 24-h AVB treatment

$* \mathrm{P}<0.05$, ** $\mathrm{P}<0.001$ compared to control group.

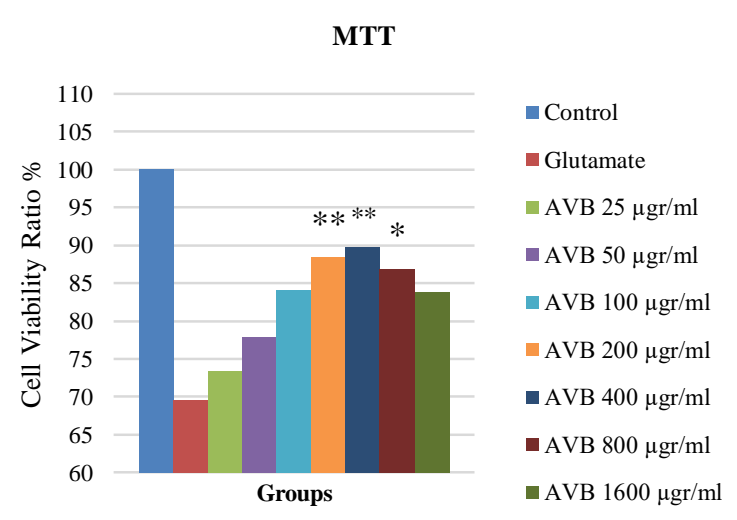

Figure 2. 3-(4,5-dimethylthiazol-2-yl)-2,5-diphenyltetrazolium bromide (MTT) assay results for the Glutamate induced toxicity in the neuron cell line after 24-h AVB treatment

$* \mathrm{P}<0.05$, ** $\mathrm{P}<0.001$ compared to control group.

When the antioxidant results in Figure 3-6 were examined, it was seen that AVB increased the antioxidant level in a dose-dependent manner against glutamate. The highest antioxidant value was observed in the AVB 400 $\mu \mathrm{gr} / \mathrm{mL}$ group (1.4-fold increase in antioxidant value against glutamate). When the antioxidant effects of AVB against glufosinate toxicity were examined, it was determined that the AVB $200 \mu \mathrm{gr} / \mathrm{mL}$ group increased antioxidant by 1.3. When the TOS results in Figure 3 were observed, it was determined that the oxidant level decreased depending on the increasing dose. It was determined that the best protection against glutamate toxicity was in the AVB 200 and AVB $400 \mu \mathrm{gr} / \mathrm{mL}$ groups, which reduced the oxidant level by 1.5 times. When the TOS results in glufosinate toxicity were examined, we found that the $\mathrm{AB} 200 \mu \mathrm{gr} / \mathrm{mL}$ group decreased the oxidant level 1.5 times. 


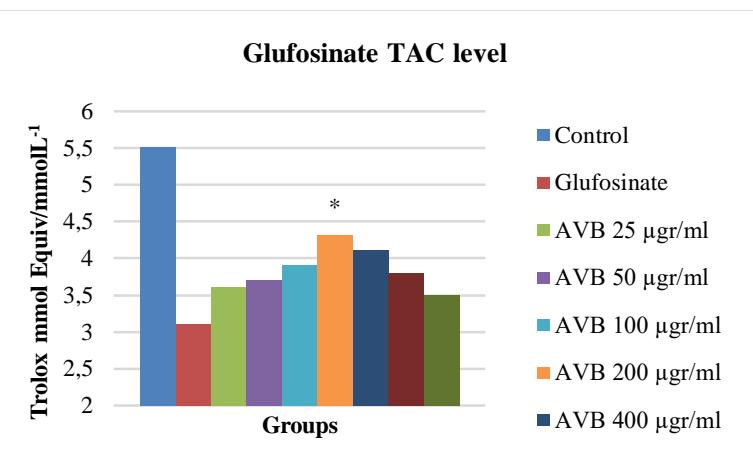

Figure 3. Total antioxidant capacity assay results for the Glufosinate induced toxicity in the neuron cell line after 24-h AVB treatment. $* \mathrm{P}<0.05$, ** $\mathrm{P}<0.001$ compared to control group.

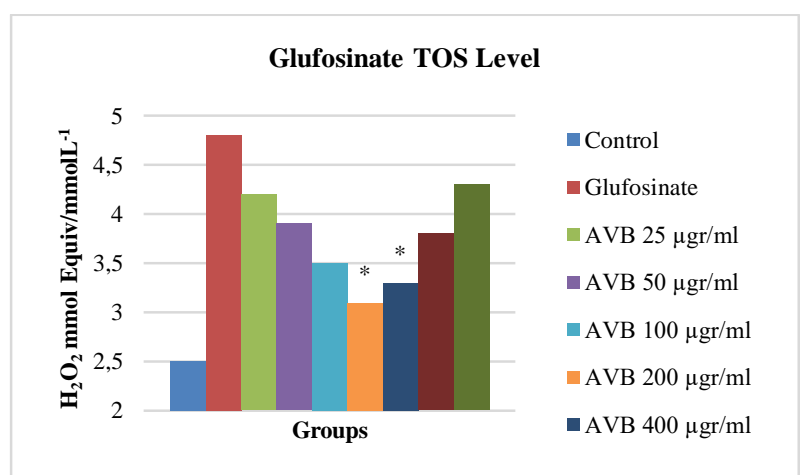

Figure 4. Total oxidant status assay results for the Glufosinate induced toxicity in the neuron cell line after $24-\mathrm{h}$ AVB treatment.

$* \mathrm{P}<0.05, * * \mathrm{P}<0.001$ compared to control group.

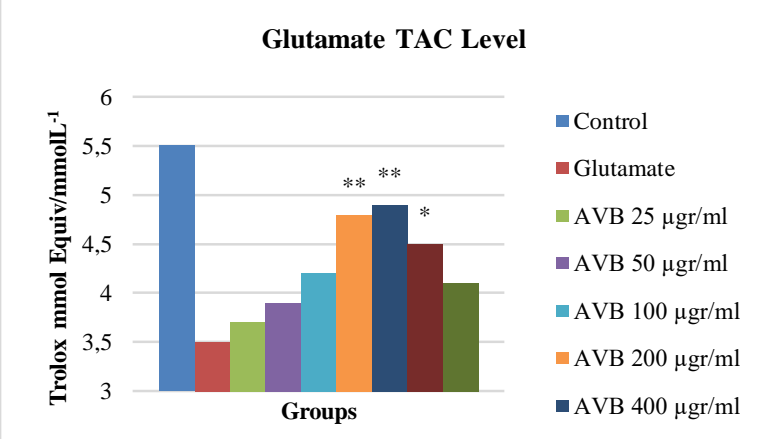

Figure 5. Total antioxidant capacity assay results for the Glutamate induced toxicity in the neuron cell line after 24-h AVB treatment $* \mathrm{P}<0.05, * * \mathrm{P}<0.001$ compared to control group.

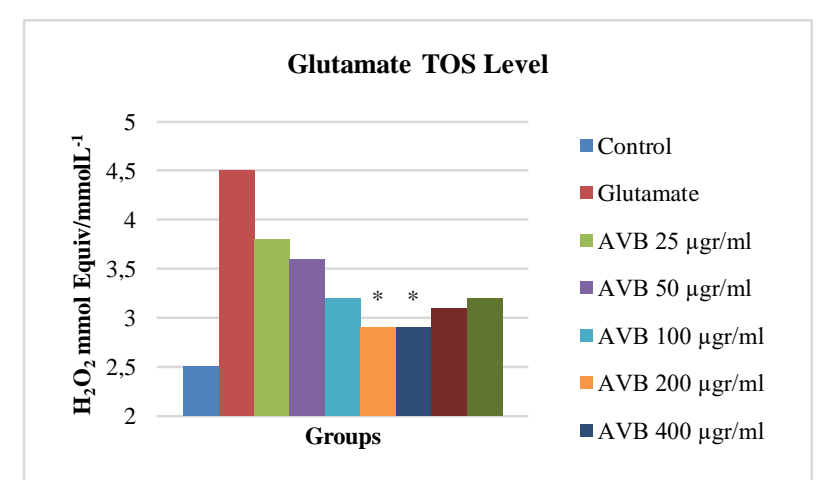

Figure 6. Total oxidant status assay results for the Glutamate induced toxicity in the neuron cell line after 24-h AVB treatment

$* \mathrm{P}<0.05, * * \mathrm{P}<0.001$ compared to control group.

\section{DISCUSSION}

In our study, the protective effects of Aloe vera barbadensis on neuronal cells against glutamate and glufosinate were investigated. Traditional medicine plays a critical role in the treatment of various types of diseases (Chinchilla et al., 2013). Nowadays, the use of complementary medicine and natural products has been increasing rapidly worldwide because they are effective and inexpensive and have fewer side effects. AVB contains several biologically active constituents, including vitamins, minerals, saccharides, amino acids, anthraquinones, enzymes, lignins, saponins, and salicylic acids (Mahboubi, 2021).

Medicinal plants contain various types of constituents, such as vitamins, amino acids, carbohydrates, and phenolic compounds. These compounds are active in controlling or neutralizing the reactive oxygen species (ROS). AVB also has function like an antioxidant through free radical- and superoxide radical-scavenging activities and antiinflammatory activities (Pandhair et al., 2011; Parmar \& Jasrai, 2009,).

Recent studies have shown that the application of glutamate to cortical and hippocampal axon terminals triggered exocytotic process, which appeared to be, at least partially, mediated by the efflux of $\mathrm{Ca}^{2+}$ ions from internal stores (Tarasenko et al., 2012). In light of the latest findings showing a close relationship between spontaneous transmitter release, $\mathrm{Ca}^{2+}$ efflux from internal stores and reactive oxygen species (ROS) generation (MartinezSanchez et al., 2020). The TAS and TOC tests were showed AVB 200 and $400 \mu \mathrm{gr} / \mathrm{mL}$ increased antioxidant activity while decreased oxidant status. Environmental stressors that are well known to induce oxidative stress and alterations to the cellular redox balance have been widely shown as apoptosis regulators (Peng et al., 2019). There are many evidence that glufosinate and glutamate induces cytotoxicity, oxidative damage, and apoptosis.

Examined, it was seen that AVB protected neuron viability against glutamate and glufosinate depending on the increasing dose. The best protection was seen in the AVB $400 \mu \mathrm{gr} / \mathrm{mL}$ (89\%) group against glutamate, which caused a $31 \%$ decrease in viability. The neuroprotection rate of the same group against glufosinate toxicity (reduces viability by $36 \%$ ) is $82 \%$. While it was observed that the AVB $800(86 \%)$ and $1600(83 \%) \mu \mathrm{gr} / \mathrm{mL}$ groups also protected neuron cells against glutamate, the viability was decreased compared to the AVB $400 \mu \mathrm{gr} / \mathrm{mL}$ group. In glufosinate toxicity, viability was $8 \%(78 \%)$ lower in the AVB $800 \mu \mathrm{gr} / \mathrm{mL}$ group and $13 \%(70 \%)$ in the AVB 1600 $\mu \mathrm{gr} / \mathrm{mL}$ group against glutamate toxicity.

When the antioxidant results in Figure 3-6 were examined, it was seen that AVB increased the antioxidant 
level in a dose-dependent manner against glutamate. The highest antioxidant value was observed in the AVB 400 $\mu \mathrm{gr} / \mathrm{mL}$ group (1.4-fold increase in antioxidant value against glutamate). Kaithwas et al. also stated that the antioxidant effects of aloe vera increased depending on the dose, and they observed the best antioxidant effect especially at the highest dose they used, $120 \mu \mathrm{gr} / \mathrm{mL}$ (Kaithwas et al., 2014). In our study, when the antioxidant effects of $\mathrm{AB}$ against glufosinate toxicity were examined, it was determined that the AVB $200 \mu \mathrm{gr} / \mathrm{mL}$ group increased the antioxidant by 1,3 . When the TOS results in Figure 3 were observed, it was determined that the oxidant level decreased depending on the increasing dose. It was determined that the best protection against glutamate toxicity was in the AVB 200 and AVB $400 \mu \mathrm{gr} / \mathrm{mL}$ groups, which reduced the oxidant level by 1.5 times. When the TOS results in glufosinate toxicity were examined, we found that the AVB $200 \mu \mathrm{gr} / \mathrm{mL}$ group decreased the oxidant level 1.5 times. Kang et al., in their study with Aloe vera barbadensis miller component on Vero cells, seems to protect cell viability against AAPH-induced cell death (400 $\mu \mathrm{gr} / \mathrm{mL}$ group). Again, protection was found in cells against AAPH-derived ROS products (Kang et al., 2014).

When high doses of AVB ( 400 and $800 \mu \mathrm{gr} / \mathrm{mL}$ ) were examined, no effective protection was observed in neuronal cells against toxicity. In various studies, negative conditions such as decreased central nerve activity, slower growth, and diarrhea have been detected in rats as a result of high-dose aloe vera application (Herlihy et al., 1998; Herlihy et al., 1998; Shah et al., 1989).

\section{CONCLUSION}

Aloe vera, which has been used since ancient times, is very common, especially for skin, inflammation, and diabetes. With today's studies, its anti-cancer, antioxidant properties have made it an even more important compound. Although its effect on healthy and cancer cells is little known, its protective effect on neurons has not been clarified yet. Our study especially reveals its effect on neurons and hopes to be a pioneer for future studies. In our study, the protective effects of aloe barbadensis against toxicity (glutamate and glufosinate) especially on neurons were revealed. It has been demonstrated with its antioxidant effects that it can be used to reduce side effects against any component with known toxic properties. In summary, the protective effects of aloe barbadensis can be used both in practice and inspire future studies.

\section{ACKNOWLEDGMENT}

A. Türkmen thanks to the council of higher education (YOK) for 100/2000 scholarships.

\section{REFERENCES}

Cattani, D., Cesconetto, P.A., Tavares, M.K., Parisotto, E.B., Oliveira, P.A.D., Rieg, C.E.H., Leite, M.C., Prediger, R.D.S., Wendt, N.C., Razzera, G., Filho, D.W., Zamoner, A. (2017). Developmental exposure to glufosinate-based herbicide and depressive-like behavior in adult offspring: Implication of glutamate excitotoxicity and oxidative stress. Toxicology, 67-80. doi: 10.1016/j.tox.2017.06.001

Chinchilla, N., Carrera, C., Duran, A. G., Macias, M., Torres, A. \& Macias, F. A. (2013). Aloe barbadensis: how a miraculous plant becomes reality. Phytochemistry Reviews, 12(4), 581-602. doi:10.1007/s11101-013-9323-3

Comakli, S., Sevim, C., Kontadakis, G., Dogan, E., Taghizadehghalehjoughi, A., Ozkaraca, M., Aschner, M., Nikolouzakis, T. K. \& Tsatsakis, A. (2019). Acute glufosinate-based herbicide treatment in rats leads to increased ocular interleukin-1 beta and c-Fos protein levels, as well as intraocular pressure. Toxicology Reports, 6 , 155-160. doi:10.1016/j.toxrep.2019.01.004

Kaithwas, G., Singh, P. and Bhatia, D. (2014). Evaluation of in vitro and in vivo antioxidant potential of polysaccharides from Aloe vera (Aloe barbadensis Miller) gel. Drug and Chemical Toxicology, 37(2), 135-143. doi: 10.3109/01480545.2013.834350

Kang, M. C., Kim, S. Y., Kim, Y. T., Kim, E.-A., Lee, S.-H., Ko, S.-C., Wijesinghe, W., Samarakoon, K. W., Kim, Y.-S., Cho, J. H., Jang, H. S. \& Jeon, Y.J. (2014). In vitro and in vivo antioxidant activities of polysaccharide purified from aloe vera (Aloe barbadensis) gel. Carbohydrate Polymers, 99, 365-371.doi: 10.1016/j.carbpol.2013.07.091

Khanal, M., Lamichhane, S., Bhattarai, A., Kayastha, B. L. \& Labh, S. N. (2021). Extract of Aloe vera (Aloe barbadensis Miller) enhances the growth, protein contents, and gastrosomatic index (GaSI) of common carp cyprinus carpio. Journal of Nutrition and Metabolism, 2021:8029413.doi: $10.1155 / 2021 / 8029413$

Kumagai, A., Sasaki, T., Matsuoka, K., Abe, M., Tabata, T., Itoh, Y., Fuchino, H., Wugangerile, S., Suga, M., Yamaguchi, T., Kawahara, H., Nagaoka, Y., Kawabata, K., Furue, M. K. \& Takemori H. (2019). Monitoring of glutamateinduced excitotoxicity by mitochondrial oxygen consumption. Synapse 73(1):e22067. doi: 10.1002/syn.22067.

Klaikeaw, N., Wongphoom, J., Werawatganon, D., Chayanupatkul, M., Siriviriyakul, P.. (2020) Anti-inflammatory and anti-oxidant effects of aloe vera in rats with non-alcoholic steatohepatitis. World Journal of Hepatology, 12(7), 363-377. doi: 10.4254/wjh.v12.i7.363

Singh, S., Kumar, V., Gill, J.P.K., Datta, S., Singh, S., Singh, V., Kapoor, D., Wani, A.B., Dhanjal, 
D.S., Kumar, M., Harikumar S.L. \& Singh J. (2020). Herbicide glufosinate: toxicity and microbial degradation. International Journal of Environmental Research and Public Health, 17(20):7519. doi: 10.3390/ijerph17207519.

Levine, S. L., Webb, E. G. \& Saltmiras, D. A. (2020). Review and analysis of the potential for glufosinate to interact with the estrogen, androgen and thyroid pathways. Pest Management Science, 76(9), 2886-2906. doi: 10.1002/ps.5983

Mahboubi, M. (2021). Aloe Vera (Aloe barbadensis) gel for the management of gastroesophageal reflux disease (GERD). Natural Products Journal, 11(1), 13-20. doi: 10.2174/2210315509666191114141533

Martinez-Sanchez, A., Lopez-Canavate, M. E., GuiraoMartinez, J., Roca M. J. \& Aguayo E. (2020). Aloe vera flowers, a byproduct with great potential and wide application, depending on maturity stage. Foods, 9(11), 1542. doi: 10.3390/foods9111542

Matozzo, V., Fabrello, J., and Marin, M.G. (2020). The effects of glufosinate and its commercial formulations to marine invertebrates: a review. Journal of Marine Science and Engineering, 8(6), 399. doi: 10.3390/jmse8060399

Pandhair, V., Diviya, J., Joginder, S. and Gosal, S.S. (2011). Biochemical studies of Aloe vera (Aloe barbadensis Miller) gel of the field grown and micropropagated plants at different developmental stages. Journal of Plant Biochemistry and Biotechnology, 20(2), 283287.doi: 10.1007/s13562-011-0040-y

Parmar, V. R. \& Jasrai Y. T. (2009). Micropropagation of an important medicinal plant aloe barbadensis mill (Aloe vera $L$ ) for field plantation. Research Journal of Biotechnology, 4(1), 7-10.

Peng, J. J., Lin, S. H., Liu, Y.T., Lin, H.C., Li, T.N. \& Yao, C.K. (2019). A circuit-dependent ROS feedback loop mediates glutamate excitotoxicity to sculpt the Drosophila motor system. Elife, 8 : e47372. doi: 10.7554/eLife.47372

Pereira, H.A., Hernandes, P.R.T., Netto, M.S., Reske, G.D., Vieceli, V., Oliveira, L.F.S. \& Dotto, G.L. (2021). Adsorbents for glufosinate removal in contaminated waters: a review. Environmental Chemistry Letters, 19(2), 1525-1543. doi: 10.1007/s10311-020-01108-4

Sevim, C., Comakli, S., Taghizadehghalehjoughi, A., Ozkaraca, M., Mesnage, R., Kovatsi, L., Burykina, T.I., Kalogeraki, A., Antoniou, M.N. \& Tsatsakis A. (2018). An imazamox-based herbicide causes apoptotic changes in rat liver and pancreas. Toxicology Reports, 6, 42-50. doi: 10.1016/j.toxrep.2018.11.008

Shah, A. H., Qureshı, S., Tarıq, M., Ageel, A.M., (1989). Toxicity studies on 6 plants used in the traditional arab system of medicine. Phytotherapy Research, 3(1), 25-29. doi: 10.1002/ptr.2650030107

Taghizadehghalehjoughi, A., Hacimuftuoglu A. \& Yilmaz A. (2019). Na+ channel blocker enhances metformin effects on neuroblastoma cell line. Medicine Science, 8(3), 636-40. doi: 10.5455/medscience.2019.08.9038

Tarasenko, A., Krupko, O. \& Himmelreich, N. (2012). Reactive oxygen species induced by presynaptic glutamate receptor activation is involved in $[\mathrm{H}-$ 3]GABA release from rat brain cortical nerve terminals. Neurochemistry International, 61(7), 1044-1051. doi: 10.1016/j.neuint.2012.07.021.

Tehse, J. \& Taghibiglou, C. (2019). The overlooked aspect of excitotoxicity: Glutamate-independent excitotoxicity in traumatic brain injuries. European Journal of Neuroscience, 49(9), 11571170. doi: 10.1111/ejn.14307.

Varmazyari, A., Taghizadehghalehjoughi, A., Sevim, C., Baris, O., Eser, G., Yildirim, S., Hacimuftuoglu, A., Buha, A., Wallace, D.R., Tsatsakis, A., Aschner, M. \& Mezhuev, Y. (2020). Cadmium sulfide-induced toxicity in the cortex and cerebellum: In vitro and in vivo studies. Toxicology Reports, 7, 637-648. doi: 10.1016/j.toxrep.2020.04.011

Zhao, H., Sun, P., Fan, T., Yang, X., Zheng, T. \& Sun, C. (2019). The effect of glutamate-induced excitotoxicity on DNA methylation in astrocytes in a new in vitro neuron-astrocyte-endothelium co-culture system. Biochemical and Biophysical Research Communications, 508(4), 1209-1214. doi: 10.1016/j.bbrc.2018.12.058. 